\title{
From Photojournalist to Memory Maker: Evgenii Khaldei and Soviet Jewish Photographers
}

\author{
David Shneer
}

About half the Russian photographers who documented the construction of the new Soviet society and its near destruction at the hands of the Nazis during World War II were Jews. ${ }^{1}$ Arkadii Shaikhet, Aleksandr Grinberg, Mark Markov-Grinberg, Dmitrii Baltermants, Max Alpert, and Evgenii Khaldei all moved to the capital of the Communist world, Moscow, from their towns and cities throughout Ukraine and Belarus to document the revolution, and later to bear witness to the Holocaust. The connection between war photography and Jews was so natural in the wartime Soviet Union that several pop cultural references explicitly make the connection. Konstantin Simonov's Zhivye $i$ mertvye (The Living and the Dead) features a heroic frontline Jewish photographer, and the popular film Zhdi menia (Wait for $\mathrm{Me}$ ) focuses on another heroic, martyred Jewish photojournalist. Among the most well-known reallife wartime photojournalists was Evgenii (Efim) Ananievitch Khaldei. This paper will examine how changing responses to Khaldei as a Soviet and Jewish photographer changed Khaldei's own sense of himself as a Soviet citizen, a photojournalist, and as a Jew.

To understand Khaldei's trajectory, it is necessary to go back a generation to the beginning of Soviet photojournalism. In the first two decades after the 1917 Revolution, photography became a craft and art form that was deeply embedded in the Soviet revolution. In the same period, Soviet photography was also defined by the social revolution transforming Russian Jewish society. Many young Jews from the provinces were at the forefront of Soviet photography, because it was a new technology that required entrepreneurialism and experimentation, something with which Jews in Russia had much experience. 


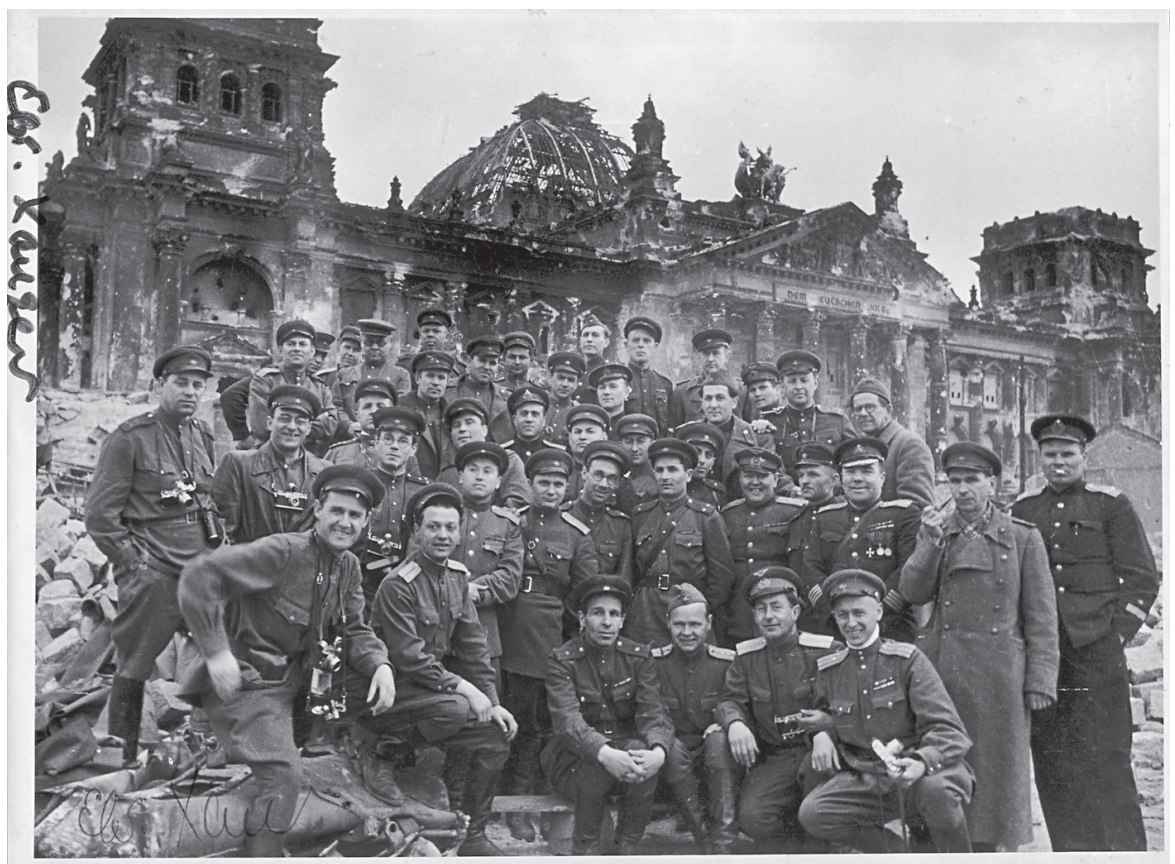

Fig. 9.1. Soviet Photo- and Print Journalists at Reichstag, May 1945.

Courtesy of Evgenii Khaldei and the Fotosoyuz Agency.

It was an easy-to-learn art form that did not have art councils, salons, and schools to restrict Jews' access, as had been the case for other forms of art for much of the tsarist era. Perhaps most important, it was a new means of making a living in a society that put new visual technologies, like film and photography, at the center of socialist culture.

Photography had a rough start in the new Communist country. With the impoverishment of Russia as a result of World War I, revolution and civil war, and closed borders that prevented the import of most photographic material, the field of photography, which had been well established in Russia since the mid-nineteenth century, shriveled and nearly died. ${ }^{2}$ In 1923 Mikhail Koltsov (who, like many other Soviet Jewish intellectuals, changed his name from the more "Jewish"-sounding Fridliand) founded Ogonek, the most important illustrated magazine in the new country, dedicated to describing life and the news for a mass audience through the lens of the modern, hand-held camera. Koltsov was just one of many starry-eyed Jews from the provinces, who moved to Moscow looking for work and escaping the impoverishment 
of war-ravaged southern Russia. It was a privilege of mobility that most Jews, and most Russians for that matter, were experiencing for the first time, because the fall of the tsars meant the temporary end of residency restrictions.

Koltsov's Moscow photographic operation, which grew from one magazine into an entire conglomerate of newspapers, magazines, and publishing houses, was not only popular with readers, but also with budding photographers. ${ }^{3}$ The magazine quickly garnered a reputation as the first stop for young, culturally and visually curious, but relatively uneducated Jewish migrants. Abram Shmuelovitch Shoykhet was born in 1898 in Nikolaev, in the Odessa region, and moved to Moscow in 1920. Like Mikhail, young Abram Shmuelovitch changed his name to Arkadii Samoilovitch Shaikhet, in his attempt to take on a revolutionary, and less provincially Jewish, persona. In 1923, Shaikhet met Koltsov and showed him some of his retouched work and his own photographs that had been published in another popular Soviet newspaper that employed many Jewish migrants, The Worker's Newspaper (Rabochaia gazeta), and Koltsov was sold. Many others would follow Shaikhet into Koltsov's office. Thus began a trend of budding Jewish photographers, arriving in Moscow desperate for work, and a sense of community among other Jews who left their homes to be part of the revolution. One of the first stops was always to meet Koltsov and hopefully find an internship or work either at Ogonek or at one of the other publications connected with the magazine.

These two 25-year-olds quickly became the leaders of a cultural phenomenon-the emergence of an institution called Soviet photojournalism. Although photojournalism emerged worldwide in the 1920s due to technical improvements in camera size, means of transmitting images, and printing techniques, photojournalism also emerged in the Soviet Union as a new society was taking shape. Soviet photojournalism, then, was documenting the "building of socialism" more than it was a new tool to capture the day's news visually.

Max Alpert, born in Simferopol in 1899, ended up in Moscow in 1924 and worked for The Worker's Newspaper too. For two years he served as photo editor of Pravda, the voice of the Communist Party and most important newspaper in the country. ${ }^{4}$ Eleazar Langman, born in 1895 in Odessa, moved to Moscow to study music before finding his way into photography with the avant-garde photography group October. Semen Osipovitch Fridliand, born in 1905 in Kiev, moved to Moscow in 1925 and immediately started photographing for Ogonek. It could not have hurt that Mikhail and Semen were cousins. ${ }^{5}$ A very young Mark Markov-Grinberg, born in 1907 in Rostov, 
moved to Moscow in 1926 and interned with several trade union newspapers. ${ }^{6}$ And Georgii Zelmanovitch, born in Tashkent, made a name for himself in the 1920s photographing the ethnic diversity of the Soviet empire. He too moved to Moscow, and in the 1930s, was a collaborator on one of Maxim Gorky's magazines, USSR in Construction, probably the most important illustrated magazine of the 1930s.

This group was the first generation of Soviet photojournalists. Among them were many young Jews raised in the tsarist empire, some of them steeled in war and revolution, who had moved to Moscow to flee poverty and to be at the center of the revolution. Through the 1920s and into the 1930s, they argued about the nature of Soviet photography and photojournalism on the pages of the magazines and journals that they themselves created. And all of them were dedicated to laying the groundwork for a profession that would become young Evgenii Khaldei's life.

This first generation of photographers attracted and mentored the second generation of Soviet Jewish photojournalists, born between 1910 and 1920, who came to Moscow as Soviet Jews, and became photographers in the Stalinist 1930s. These photographers, like Evgenii Khaldei, Dmitrii Baltermants, Iakov Khalip and others, had a different relationship to photography. They did not grow up in the "fire of revolution," they did not have to build a profession, and they did not have to fight on the pages of photo magazines about what Soviet photography was supposed to be. In fact, unlike the first generation, which wrote prolifically to answer the question "what is Soviet photography," the second generation inherited the answer. They entered a well-formed, stable profession called photojournalism, passed down from the "fathers," now ancient at the age of 40. (There were virtually no "mothers" in this burgeoning field. The only well-known female Jewish photographer, Olga Lander, is of the second generation.)

Khaldei's life story is one of the most well known among this group of Soviet Jewish photographers. In the 1990s, after the fall of the Soviet Union, he gave interviews, told stories, and even had a documentary film made about him in which his Jewishness played a central role in his life story. Born in 1917 in the eastern Ukrainian city of Iuzovka (later Stalino, and later still Donetsk), Khaldei was raised in a Yiddish-speaking Jewish family on the cusp of modernity. His grandfather ran a traditional Jewish school known as a heder. During the Civil War that wreaked havoc on Russian society, a wave of pogroms broke out across Ukraine. Hundreds of thousands of Jews were killed, 


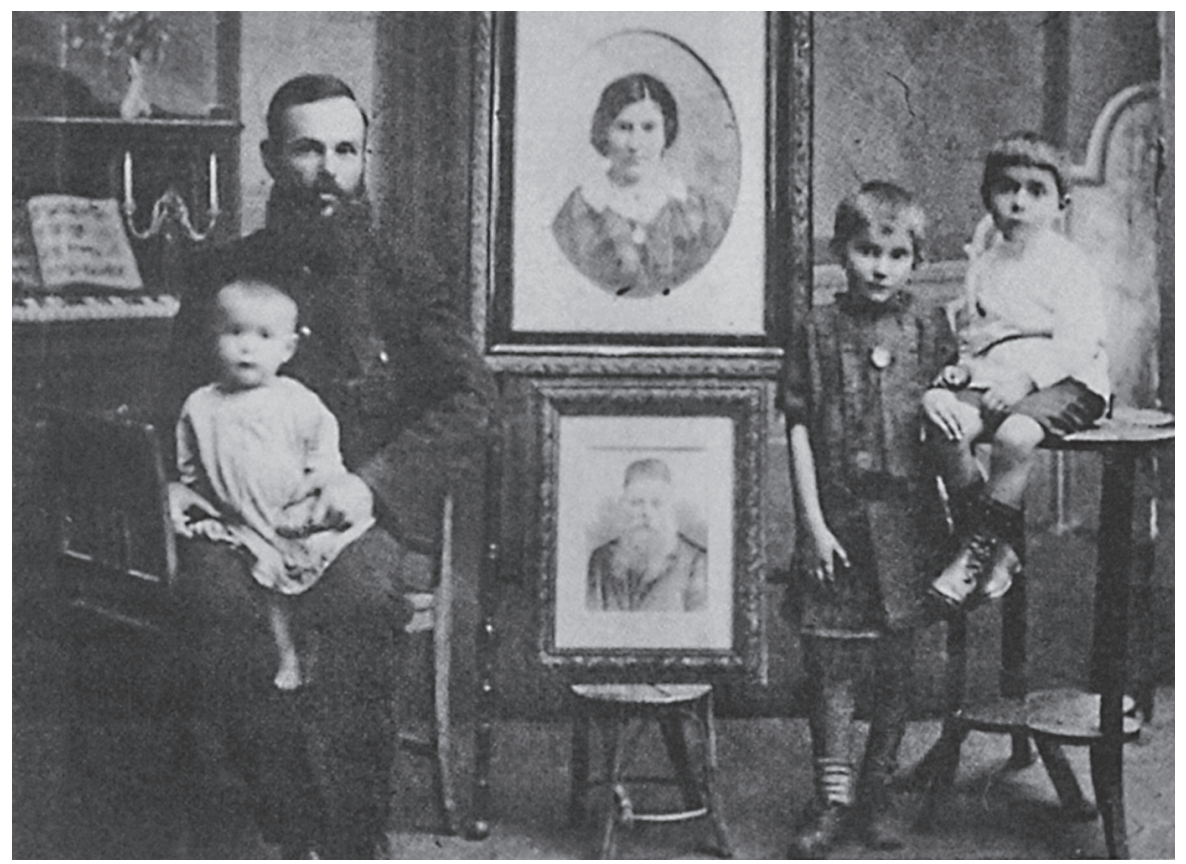

Fig. 9.2. Khaldei's Family in 1920.

Courtesy of Evgenii Khaldei and the Fotosoyuz Agency.

and perhaps millions more were forced from their homes or migrated abroad. Young Zhenia watched his mother and grandfather get killed in one of these pogroms; he was too young to remember the experience, but the memories of these anti-Jewish riots had a powerful influence on him and his family.

Khaldei did not excel at academics, and as a young teenager he had to choose where to apprentice for his future profession. He started working as a metalworker in a factory, but he quickly became more interested in photography and began playing with cameras. One of his earliest photographs was of the destruction of a local church during the anti-clerical campaign of the Cultural Revolution in 1931-32. The earliest evidence of Khaldei's professional photographic career comes from 1932, when he freelanced for the Donetsk division of the press photography unit of the Ukrainian Photo Union. He also faked his birth date in order to start working earlier than he was allowed. All of his official documents give his birth date as 1916, a fiction invented in a job interview in $1932 .{ }^{7} \mathrm{He}$ worked for several local publications as a photographer but got his big break in 1935, when he was invited to Moscow to attend a 
photography seminar at Soiuzfoto, what would become Fotokhronika TASS, the largest photography wire service in the country. ${ }^{8}$ In 1936 he moved from Stalino to Moscow, which he would call home for the rest of his life.

Khaldei entered a Stalinist system of cultural production, in which photography was less about creative genius than it was about doing a job as outlined by an editor. In 1934, socialist realism had been enshrined as the official aesthetic of the Soviet Union, and modernist aesthetics were in theory decried as putting form ahead of content and politics. In addition to a changed political and aesthetic framework of photography, Khaldei entered a centralized system for producing culture, in this case the process of training photographers, organizing publications, establishing editorial policies, making photographic assignments, and shaping the process from camera-click to published image. Stalinist-era photography production was defined by large, overarching professional unions under Communist Party control and through centralized bureaucracies that controlled photographic subject matter and editorial policies.

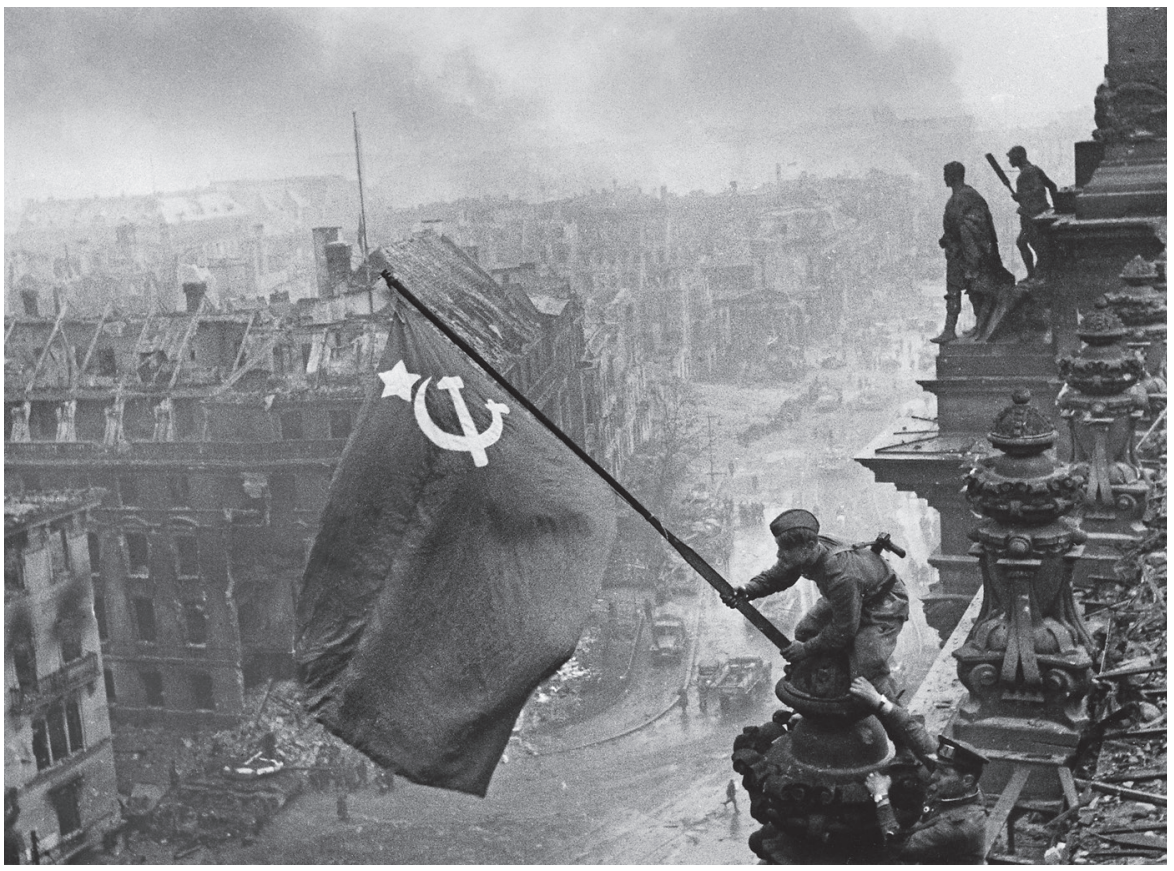

Fig. 9.3. Evgenii Khaldei, "Raising the Red Flag over Reichstag."

Courtesy of Evgenii Khaldei and the Fotosoyuz Agency. 
Khaldei trained as a photographer in this world, but he became well known only during World War II, an event that catapulted all of the secondgeneration photographers into the ranks of the most important photographers in the country. Khaldei photographed the war from beginning to end, from the Arctic to the Black Sea, from Berlin in the West to the Chinese border in the East. His work with the Black Sea fleet was deemed so important that in 1942 the 26-year-old Khaldei was promoted to a higher rank. ${ }^{9}$ His most famous photograph, "Raising of the Red Flag over the Reichstag," crowned his career as a military photographer, even though he continued photographing the war with Japan in August and September 1945. Khaldei was at the peak of his career when he was invited to photograph the post-war Nuremberg Trials and the Paris Peace Conference in 1946.

In addition to his relatively well-known career as a photographer of Soviet victory, Khaldei also photographed the darkest story of the war-Nazi atrocities against Jews, what we now call the Holocaust. Everyone in the Soviet Union knew about the Nazi atrocities, which were widely publicized in the Soviet press from the first days of the war. Ogonek published its first photo of such horrors on June 25, 1941, its first edition following the invasion, and a gruesome image it was. ${ }^{10}$ At first, the Soviet press published perpetrator photographs, like the one above-those taken by the Germans, Nazis, and other collaborators themselves, which were then captured and made their way to Moscow as "trophy photographs." But it did not take long for the Soviet press's own photographers to bear witness to Nazi crimes. In January 1942, Khaldei, Baltermants, and Mark Redkin photographed the southern city of Kerch', where the Nazis killed thousands of Jews. The city had been held by the Germans for only six weeks, from mid-November until late December 1941, but in that time, much of the city's Jewish population had been rounded up, sent to the outskirts of town to a trench near the suburb of Bagerov, and shot. ${ }^{11}$ Kerch' would very quickly become one of the earliest and most important symbols of Nazi brutality in the Soviet Union. This happened through literary representations of the event like Il'ia Ehrenburg's 1943 book Russia at War, which talks about the "terrible pit near Kerch" in which the children of Russians, Tatars and Jews are buried"; Il'ia Sel'vinskii's "Ia eto videl" (I Saw It), the subject of Harriet Murav's essay in this volume; and through photographs published in all of the major press. ${ }^{12}$

The photographers were on the scene shortly after liberation in early January and photographed an unbelievable scene of mass murder. Khaldei 


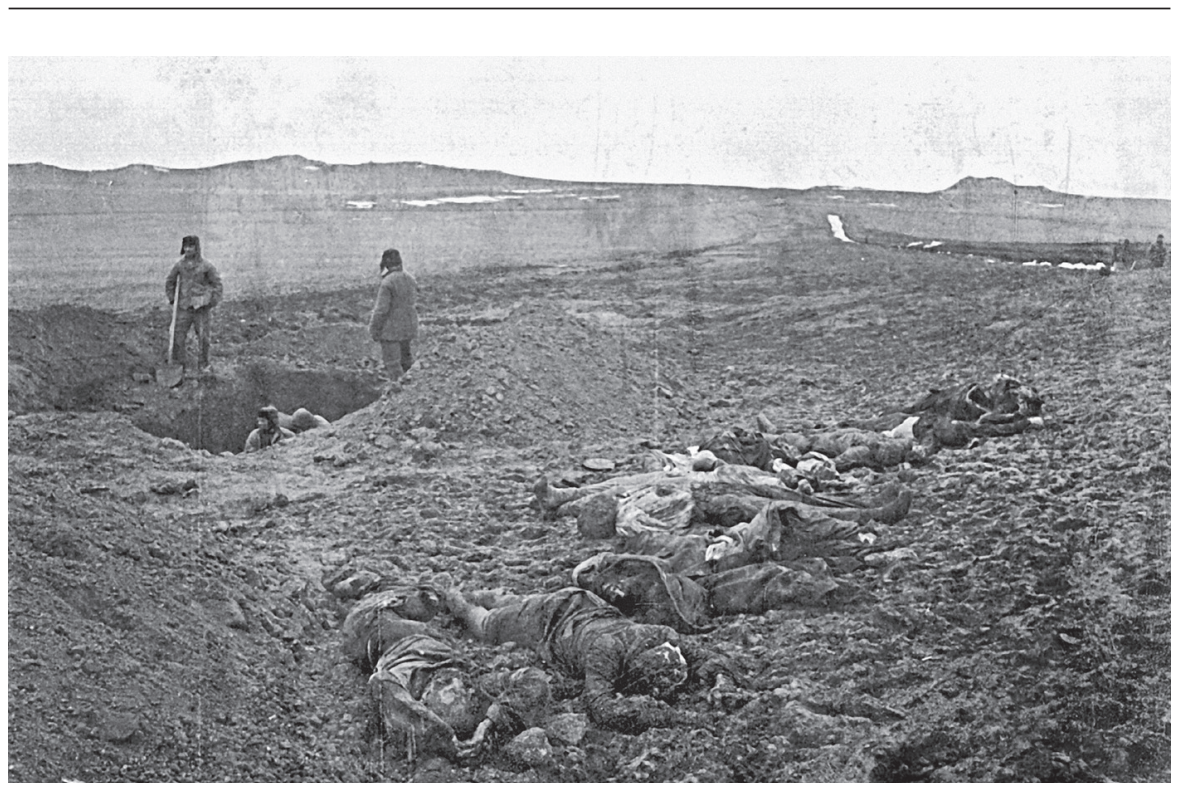

Fig. 9.4. Evgenii Khaldei, "Sonits Dig a Grave."

Courtesy of Evgenii Khaldei and the Fotosoyuz Agency.

writes in his diary about how he, as a photojournalist, collected stories from survivors and family members of the dead, who told him about the mass murder of Kerch"s Jews. ${ }^{13}$ (See Figure 9.4.) Although Khaldei's photographs did not appear in the central press at the time, Baltermants' and Redkin's photographs were splashed across the pages of Ogonek, the most important illustrated journal in the country.

The caption beneath Redkin's photographs, which appeared on February 4,1942 , suggests how he and the Ogonek editors placed atrocity photographs into an evolving narrative of the war: "Hitler ordered his bandits to annihilate the peaceful Soviet population. Wherever the Germans found themselves, they murdered thousands of women and children. The bodies of the murdered were dumped in a pit (see top photograph). Among the murdered were many women and children (see bottom photograph). The Hitlerite thugs showed no one any mercy." The caption obscures the perpetrators of the crimes. In one sentence they are followers of Hitler; in another, Germans. No mention is made of the fact that most of the dead women and children so grotesquely splashed across the pages of the magazine were Jewish.

One month later, Ogonek followed up its earlier Kerch' images with a two-page layout of photographs by Dmitrii Baltermants and Israel Ozerskii 
and an article by the journalist I. Antselovich, all three of whom were Jewish. The headline reads: "These photographs were taken after the German occupiers drove [the people] out to this place. 7,500 residents, from the very elderly to breastfeeding babies, from just a single city were shot. They were killed in cold blood in a premeditated fashion. They were killed indiscriminatelyRussians and Tatars, Ukrainians and Jews. The Hitlerites have also murdered the Soviet population indiscriminately in many other cities, villages, and in the countryside." (See Figure 9.5.) Although they appear as just one of several, Jews were clearly named among the murdered Soviet nationalities. But the captions of the Redkin and Baltermants photographs obscure a fact that all of these photographers knew-that the Nazis targeted Jews above others.

For Khaldei, the events of the Holocaust moved from the professional to the personal when he visited his hometown of Stalino shortly after the city's September 1943 liberation. There he discovered that many members of his family had been murdered, killed in mine shafts on the outskirts of town. According to Khaldei’s daughter, Anna, only his brother and sister, who

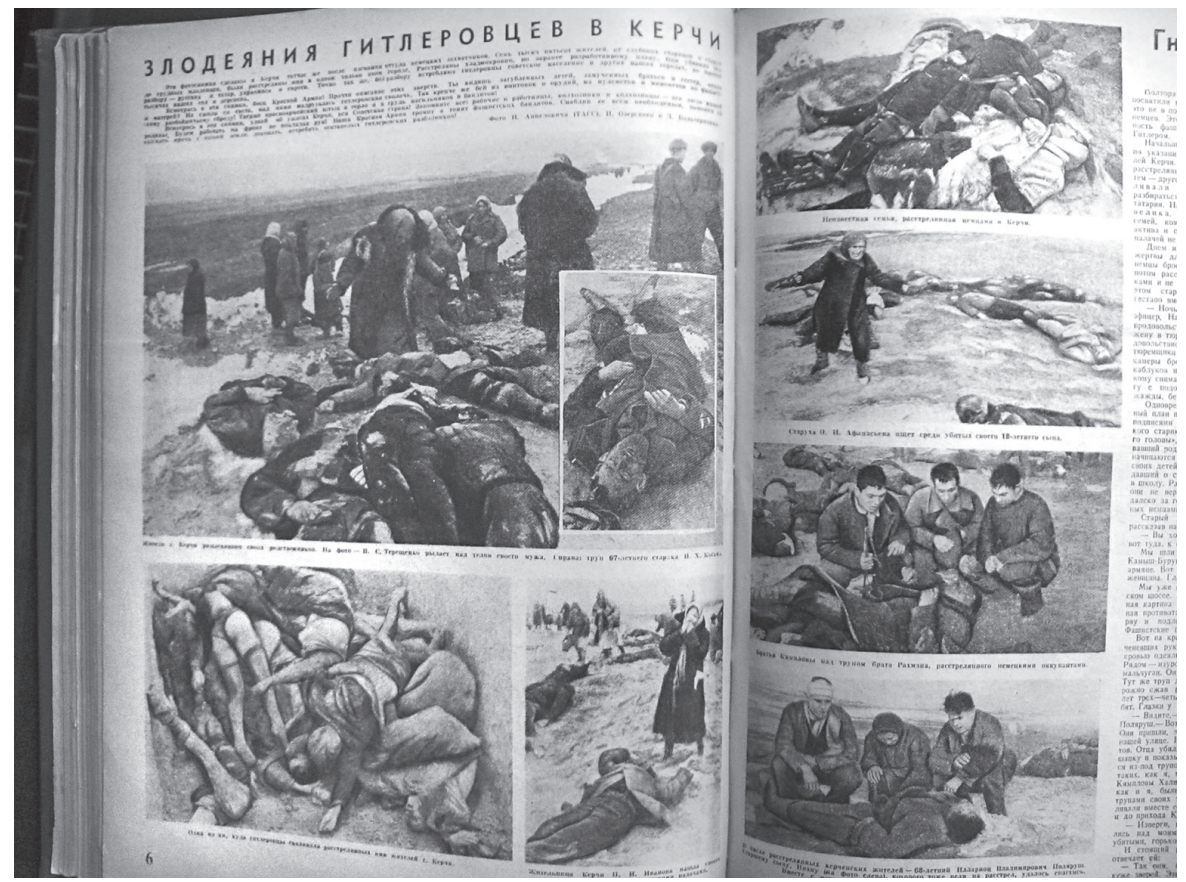

Fig. 9.5. Dmitrii Baltemants and Israel Ozerskii, "Hitlerite Atrocities in Kerch'," Ogonek, March 2, 1942. Courtesy of Evgenii Khaldei and the Fotosoyuz Agency. 
were evacuated before the Nazis reached Stalino, survived the war. ${ }^{14}$ Khaldei was transformed by the experience of seeing the violence first hand. In one interview, he claims that when he entered Germany with the troops in 1945, he sought out opportunities for revenge, and even set a German's house on fire in order to photograph it burning as Soviet troops marched by. ${ }^{15}$

But Khaldei's most powerful photographs that engaged the Jewish story of the war are of the Budapest ghetto. Khaldei accompanied the Red Army on its path of liberation through southern Russia and the Balkans, and he found himself in Budapest, Hungary in late January 1945. Khaldei made an unusual trip to the Jewish ghettoes to photograph the specific tragedy of European Jewry. ${ }^{16}$ It is not clear if he was doing this on assignment from his TASS editors. ${ }^{17}$ His trip to the ghetto was obviously more personal than his usual work at sites of liberation. He intended to bear witness to one of the last extant ghettos in all of Europe, where he could photograph Jews who survived Nazi occupation. He took many photographs of what had taken place in the Budapest ghetto in late 1944. His archive has more than a dozen images of corpses with stars sewn onto jackets, makeshift killing rooms, and mountains of destruction as the city was seared by battle in the Soviets' months-long attempt to take the city.

On March 3, 1945, about three years after the appearance of the first Holocaust liberation photographs from Kerch' in the Russian press, and about a month after he took the photographs in Budapest, a Soviet media outlet published some of Khaldei's ghetto photographs. However, they were not published in Pravda, Izvestiia, or Krasnaia zvezda, the army newspaper for which Il'ia Ehrenburg and Vasilii Grossman worked. Instead, Khaldei’s photographs appeared in the central Soviet Yiddish newspaper published during the war, Eynikayt (Unity), which ran a grim layout of Khaldei's photographs from the Budapest ghetto on the front page. ${ }^{18}$ Why the Russian-language press did not publish these images is a matter of speculation. The Russian press obviously published images of what we now call the Holocaust from the first day of the war until the last, including photographs of the extermination camps liberated by the Soviet army on Polish soil, like Majdanek and Auschwitz. But the editors of those papers, who were often Jewish themselves, were more invested in universalizing the Nazi atrocities by labeling victims as "peaceful Soviet citizens," most of whom were, of course, Jews, as we saw with the Kerch' photos. Photographs of empty burial pits, disfigured corpses, barbed wire, or gas canisters could easily be read as images that would speak to any reader of the Russian-language Soviet press. But Khaldei's Budapest 
photographs were harder to universalize. After all, most of those in his grainy black and white pictures, whether dead or among the survivors, were wearing a six-pointed Jewish star instead of the five-pointed Soviet one.

From the first weeks of its publication in June 1942, Eynikayt "judaized" the war for both its domestic and international Yiddish-reading audiences. ${ }^{19}$ Throughout 1942, Eynikayt published graphic photographs of German violence committed against Jews. There were pictures of Jewish burial sites, the Warsaw ghetto, and other images whose captions clearly noted that the people in the pictures were Jews. Unlike the Russian-language press, whose purpose was to create a nationally unifying narrative of the war, Eynikayt's role was to build support for the Soviet Union by creating connections among Yiddish-reading Jews across national borders. If the Russian press marked victims as "peaceful Soviet citizens" or "citizens of one particular nationality," a subtle way of singling out Jews without saying so, Eynikayt's identified victims unambiguously as Jews.

Since the Soviet press did not simply tell the news but always also interpreted it, the captions for individual photographs had to both describe the awful scene and help readers understand it:

Jews in Budapest. Hitlerites drove tens of thousands of Jews from all over Hungary into Budapest's ghetto region. [Pictured here is] the first building that served as the beginning of the ghetto and the store in this house, which the fascists transformed into a torture room in which they used to inflict all kinds of things on Jews, shoot them, and then toss their bodies onto the square. Thanks to the hate-driven attack of the Red Army, thanks to the fact that Soviet forces quickly encircled the city, a significant part of Hungarian Jewry was saved from murder.

In the pictures (from right to left): 1 . Budapest is liberated. Jews go in every direction back to their places of permanent residence. 2 . A mother and daughter whom the fascists dragged out from their cellar, beat in the middle of the street, and then shot. Next to them sits their husband and father. 3. Jews with yellow Stars of David. The fascists forced them to wear these on their chests. 4. A store in which Jews were shot. 5. Slaughtered Jews whom the Germans and fascists murdered before retreating from the city.

This text, along with the captions to the individual photographs, told readers that by 1945 the Soviets were liberators of Jews from Nazi atrocities, 
not victims themselves. There was no discussion of the murder of "peaceful Soviet citizens," especially given the obvious fact that Soviet troops were now in Hungary, not the Soviet Union. In addition, Eynikayt's editors chose to express both a Jewish and Soviet story. Through the use of active verbs such as "murdered," "forced," and "dragged," rather than the passive constructions that would have been more common in both Yiddish and Russian, the caption articulates a clear perpetrator, the fascists/Hitlerites/Germans, and a victim, the Jews. In Eynikayt, the Soviets' role was as heroic liberators who saved Jews-not "peaceful Hungarian citizens"-from murder and destruction. The third photograph in the series would become one of Khaldei's signature images. The photograph's caption describes the act of visually identifying people with a Jewish symbol that the Nazis had turned into a grotesque icon that flattened individual identity.

Shortly after the liberation of Budapest, Khaldei was a lead photographer documenting the conquest/liberation of Vienna and, in May 1945, of Berlin. His "Raising the Red Flag over the Reichstag" photograph is probably his most famous image, and it circulated widely in the 1960s, 1970s, and 1980s, when Soviet war memory became a monumental industry. But this photographic success during and shortly after the war did not protect him during the anticosmopolitan campaign of the late 1940s and early 1950s, when Jewish doctors, writers, artists, editors, journalists, photographers, and others were fired from their jobs, or even murdered, for having been "too Jewish" during the war. Those connected with Eynikayt, the newspaper that published Khaldei's Budapest photographs, and with the Jewish Anti-Fascist Committee were suspected of being at the center of a Jewish/Zionist nationalist conspiracy. Many of the most important Jewish culture-makers were killed. ${ }^{20}$ In this case, it's a good thing photographers were not considered important culture-makers.

Khaldei's story of running into trouble with his superiors actually began during the war in 1943. That year, David Ortenberg, editor of Red Star, was fired, as were other editors of lesser-known newspapers. And historian Gennadii Kostyrchenko marks 1943 as a point at which the state's relationship to its Jewish population took a turn for the worse. ${ }^{21}$ Although he never talked about it, in 1943, Khaldei was nearly dismissed from serving as a photographer with the Black Sea fleet for publishing photographs that had not passed through the local military censor. Only a petition from Khaldei's top boss, the head of Fotokhronika TASS, to TASS headquarters kept him at his job. In 1946, after returning to Moscow from his glory days in Germany for the 
Nuremberg Trials and Paris for the Paris Peace Conference, he was taken off of an assignment for refusing to turn in some photographic equipment that he needed to use. In 1947, he was brought before a Communist Party board to be reprimanded for his "low cultural level," and in 1948 the bombshell hit. On October 7, he received notice that he was being terminated from TASS after 12 years of employment due to "staff downsizing." ${ }^{22}$ Khaldei was one of several Jewish photographers who lost their staff positions in 1948 and worked through the late Stalin period as freelancers. Khaldei had commissions from Labor (Trud), Soviet Woman (Sovetskaia zhenshchina), VOKS (All Union Society of Foreign Cultural Relations), and others. After Stalin's death, Pravda rehired him, and Khaldei remained an important photographer for the rest of his career, especially in the 1960s, when Soviet war memory became big business. But Khaldei's photographs of the Budapest ghetto lay dormant, unpublished since the war. Although it worked as Yiddish-language news in 1945, the "Jews with Yellow Stars" of Budapest had become too Jewish for public Russian-language Soviet war memory. Khaldei never regained the prestige he had in May 1945 when he took his famous Reichstag photograph, and he died in 1997 living in a tiny apartment, poor but absolutely not forgotten.

If, during the war and in the 1960s, Khaldei was an important Soviet photographer, in the 1990s, after the fall of the Soviet Union, Khaldei became relatively famous internationally as a Soviet Jewish photographer. Just before his death in 1997, the Jewish Museum in New York and the one in San Francisco each mounted a large solo exhibition of Khaldei's work, firmly embedding him and his work in a Jewish context, and a Belgian filmmaker made a documentary about him. ${ }^{23}$ It was in this context, as part of the institutionalization of Holocaust memory in the West in the 1990s, that the Jews with Yellow stars from Budapest made a wildly successful return in the post-Soviet period as "The Jewish Couple." The stories Khaldei told about the photographs show how he refigured wartime photojournalism documenting Nazi atrocities into iconic Holocaust photography adorning the walls of museums around the world.

Khaldei loved to talk about the Jewish couple photograph. This quote is from an interview he gave to scholars Alice and Alexander Nakhimovsky, who helped organize Khaldei's launch in the American photographic market:

I saw them walking down the street. I was in a black leather coat, and at first they were afraid-they thought I was from the SS. I walked 
over and tore off their stars, first the woman's, then the man's. She got even more frightened. She said, "No, no, you can't do that, we have to wear them!' I told them that the Russians were here. I told them, "Shalom." Then she cried. ${ }^{24}$

Khaldei positions himself very clearly as a Jewish photographer-emphasized by him speaking to the couple in Hebrew, at least according to this version of the story. Another version of the interview suggests that Khaldei did not say "Shalom" in Hebrew, but that he said in Yiddish "ikh bin oykh a yid. Sholem-aleykhem" (I'm a Jew too. Hello.), a more likely scenario. Khaldei also positions himself as the Jewish couple's liberator. As he tells the story, he was in fact the one who carried out their symbolic liberation by tearing off their stars. Obviously, in the photograph, the couple still has the stars, showing that Khaldei did not, in fact, tear off the stars. I am more interested in how he refashioned his role in the scene fifty years after the fact, as the photographerliberator of his Jewish brethren on the war-torn streets of Budapest.

The photograph of the encounter, called "Jewish Couple," has adorned the walls of art galleries and Jewish museums around the world, but it is dif-

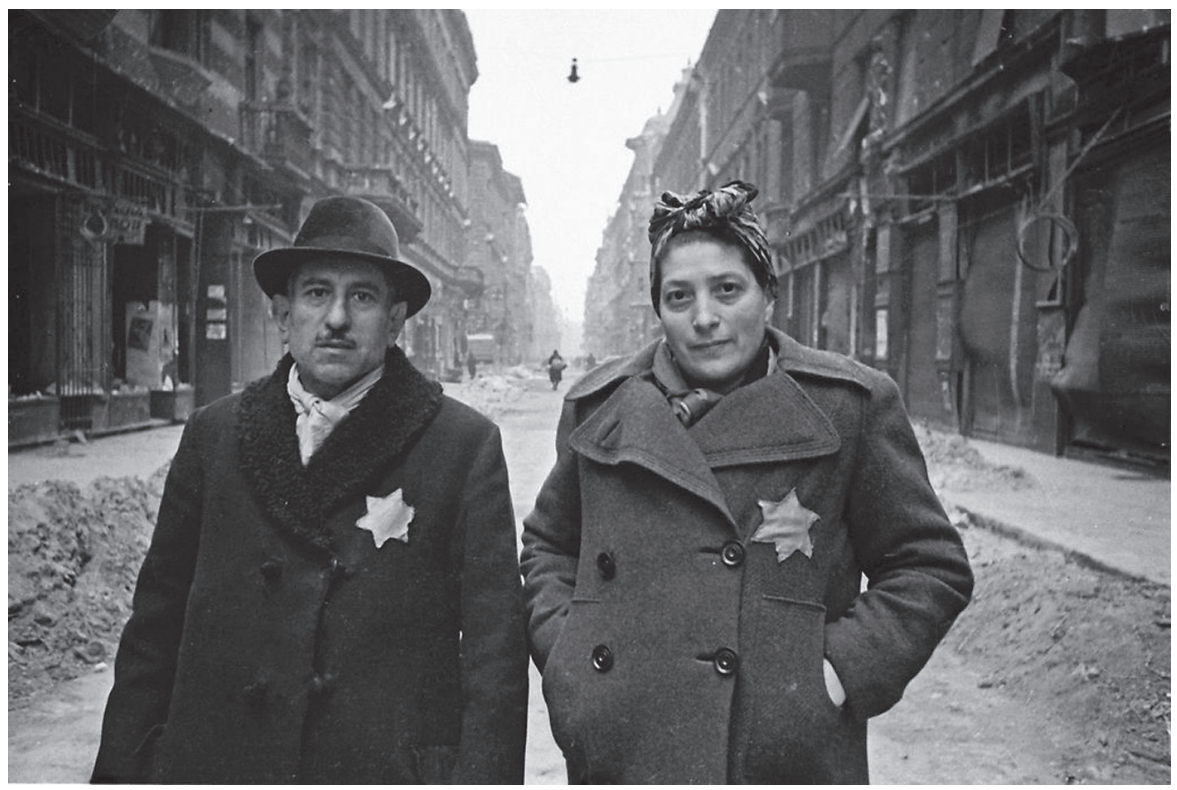

Fig. 9.6. Evgenii Khaldei, “Jewish Couple” 1945. Courtesy of Evgenii Khaldei and the Fotosoyuz Agency. 
ferent from the version published in Eynikayt during the war. First, the faded photojournalistic image in Eynikayt had a descriptive caption rather than a pithy title like "Jewish Couple." If the emphasis during the war was on the Nazis' violent act of fixing identities-marking Jews by putting yellow stars on them-then in the 1990s, the story was about the Jews themselves. The composition of the photographs is different. In the published 1945 photo, the stars are at the center of the frame. The woman looks away from the camera, suggesting disengagement with the photographer. The image is cropped close on their bodies, so the viewer sees little of the buildings and streets of the grand, but ruined city of Budapest. In the exhibition photograph of the 1990s, our gaze is directed into their faces and into the endless street behind them that suggests the long journey they have traveled and through which they have travailed. The exhibition photograph-the more compelling of the two-tells a more intimate and more profound story. "Jewish Couple" made the people, and not the wartime antisemitic laws about wearing yellow stars, the central theme.

Khaldei's story about photographing the couple shows just how invested he was in the Jewishness of his work as he presented it late in life to American, and often Jewish, audiences. His 1997 New York Times obituary talked in detail about Khaldei being raised in an "Orthodox Jewish family." 25 In fact, the word "Soviet" disappeared from his description of the photograph entirely, and the focus became the Jewishness of the encounter. (Note how he says the "Russians," not "Soviets," had arrived in Budapest.) Khaldei's photograph lost the Soviet wartime liberation story as it became an icon of Holocaust memory to the many Western audiences who lauded him and his work in the last years before his death.

However, Khaldei's post-Soviet legacy in Russia is quite different from the one in the West. As the official Soviet war narrative became the postSoviet war memory, with Jews the ever-present absence, Khaldei rarely presented himself, or his story of the Budapest ghetto, as Jewish. Rather, he presented himself and the photo as part of the heroic Soviet war memory, not as images representing the tragedy of the Holocaust. This is how Khaldei recounted the story of the Budapest photograph to a Russian journalist in the 1990s:

I was walking along a side street and I ran into these two. Although people knew that Soviet troops had entered the city, the woman 
stopped and looked distressed. I began to explain to them in German that I was Russian, Soviet. The woman began to cry. I photographed them, and then they immediately began to rip off the stars that had been sewn onto their coats.

In this interview, Khaldei does not use the word "Jew" once and instead describes himself as Russian and Soviet. He does not speak Yiddish or Hebrew to the couple, but says that he spoke German. Perhaps most important, he says that the couple tore off their own stars, rather than him doing the symbolic liberating. In framing the Holocaust for a post-Soviet Russian audience, Khaldei was Soviet, not Jewish. In the 1990s, Khaldei presented different selves and different frameworks for his photograph to audiences who, fifty years later, had very different memories of the war. In post-Soviet Russia, because of the universal memories of the war that absorbed Jewish suffering into general Soviet and human suffering, his photograph was not embedded in a separate memory of the Holocaust. It was a part of the Soviet war experience. To Western audiences, not only did he speak Hebrew or Yiddish to the Jewish couple, but he proudly proclaimed a traditional Jewish heritage. ${ }^{26}$

In all stories about the photograph, Khaldei emphasized one important point-that because of the Jewishness of the image, the photograph had never been published in the Soviet Union. As the Nakhimovskys relate in their description of the "Jewish Couple," "The image of the Jewish couple was not [publishable]. The photograph of the Jews in the synagogue appears here for the first time."27 (Why it was not publishable is not mentioned.) Both photographs, of the Jewish couple and an image of dead Jews whose bodies were strewn about a makeshift synagogue in the Budapest ghetto, were, in fact, published during the war on the pages of Eynikayt. However, more interesting than the historical truth of the publication of these photographs is Khaldei's and subsequent scholars' interest in crafting this particular history for them. The Russian journalist ended his Khaldei interview with the statement that the photograph had never been published and laid in reserve for sixty years.

In fact, every source that discusses this image and every person I interviewed for this project insisted that because of the Jewishness of the photograph, "Jewish Couple" never appeared in the Soviet Union, neither in a newspaper as photojournalism, nor in an exhibition as an art photograph recalling the war. ${ }^{28}$ We know that it did appear in Eynikayt, so why would 
Khaldei and all of these commentators tell a story of wartime censorship and repression of his Budapest photographs?

Since Khaldei was, in fact, persecuted as a Jew in the post-war period, and it was true that after the war, discussion of the Holocaust-the specific persecution of Jews by Nazis and their collaborators-was silenced, it made sense to craft a life story showing how he, his photographs, and the story of the Holocaust were repressed under Stalin. He may even have forgotten that his photographs were published during the war, since that fact was difficult to incorporate into the narrative of his post-war life. The irony is that his photographs appeared during the war, under Stalin, but they were suppressed under Khrushchev and Brezhnev, as part of the creation of Soviet war memory.

In the 2000s, two exhibitions attempted to return Khaldei and his photographs to their original context in time and place. In 2005, at the Russian State Historical Museum on Red Square in Moscow, the late Khaldei and his son Leonid, a budding photographer in his own right, had an exhibition titled "Budapest through the Eyes of Two Generations." It was the first major showing of a wide range of Khaldei's Budapest photographs and included several taken in the Budapest ghetto. Leonid went to Budapest in 2005 to take photographs for the exhibition, nicely contrasting the elder Khaldei's historic photojournalism of violence and destruction with contemporary documentary images of the newly bourgeois capital of a European Union country. Following Khaldei's self-presentation to Russian audiences as a Soviet, not Jewish, photographer, the online catalog for the exhibition makes no mention of the fact that both photographers are Jewish. In the biographical description of the elder Khaldei, it mentions nothing about pogroms or an Orthodox Jewish upbringing, like the New York Times mentioned, and says that he was fired in 1948 not because he was Jewish, but "because of what was written under 'nationality' in his passport." It is true that most visitors would know this was the same coded reference to "Jewish" as had appeared during and after the war, but as befits the Soviet and post-Soviet memory of the war, the word "Jew" never appears. ${ }^{36}$

In 2008, the German photography agency Voller Ernst mounted the largest solo show of Khaldei's work in the august Martin Gropius Bau in the center of Berlin. The exhibition included hundreds of beautiful exhibition photographs, ephemera from Khaldei's archive, and even his old camera, which was shipped from Moscow for the occasion. The German organizers 
produced an expensive glossy, several-hundred-page cloth-bound catalog with articles by several scholars, myself included. The organizers asked me explicitly to frame his story as a Jewish story, and so I titled my article "When Photography was Jewish." The title works in English as a statement about the social history of photography for an American audience that has read much scholarship and popular literature showing how migrant Jews helped build much of twentieth-century visual media. ${ }^{29}$ In German, however, the title echoed with a Wagnerian, antisemitic presumption that there was something called "Jewish photography" and, potentially, its opposite, Aryan art. It simply would not fly in that cultural and linguistic context. So in German, we titled it simply "Evgenii Khaldei and Soviet Jewish Photographers."

The comparison between the two exhibitions and the three linguistic and cultural universes represented shows how history and memory always operate in tension with one another. It is a fact that Khaldei was Jewish and that his Budapest photographs were published during the war. However, 60 years after their publication, different national memories read his photographs through different lenses. In a post-Soviet Russian context, the war against the Soviet Union is still a more powerful memory than the Holocaust is, even (or perhaps especially) for Soviet Jews who fought in the war. According to Zvi Gitelman's study of the Soviet Jewish war generation, most elderly Russian Jews understand the importance of the Holocaust to Jewish identity, but when asked about the Holocaust's role during the war, Soviet Jewish veterans told Gitelman that "they did not fight in the war as Jews but as Soviet citizens." ${ }^{30}$

In the US and Israel, Khaldei is celebrated as an important photographer and as an oppressed Soviet Jew who was persecuted despite having been a Soviet patriot who took some of his country's most important war photographs. In Germany, these stories are even more complex than the distinction between Russia’s emphasis on the Soviet war and the American and Israeli reading of the images as Holocaust photographs. The Martin Gropius Bau exhibit opened on May 8, 2008, the day marking the Soviet victory over Germany and the end of the Nazi war against the Jews. How odd it was to be in Berlin, just walking distance from the new, glass-domed Reichstag, at the largest, most expensive Khaldei exhibition in history, whose primary icon was a Soviet flag flying over the ruined Reichstag, and whose catalog opened with an article originally titled "When Photography was Jewish"!

Returning iconic photographs to their original news context shows how they function in the creation of narratives and memories. Soviet Jews, 
Khaldei among them, saw the war as many tragedies in one-personal, familial, communal, and national. And when he shot his Budapest photographs, he was taking news photos of particular aspects of this Soviet and Jewish war. His employer, the Soviet press, was the first institution to publicly develop a narrative of and an interpretive framework through which to understand Nazi atrocities, in both Russian and Yiddish. When we see these photographs in all of their historic complexity, the distance between Soviet and Jewish, and the war and the Holocaust collapses.

As for our photographer, Khaldei's story reminds us that, like the photographs, people's identities change over time and place. During the war, Khaldei was an up-and-coming Young Turk of Soviet photography. On the one hand, he ran into trouble with censorship that had nothing to do with Nazi atrocities. On the other hand, he was king of the profession, standing on top of the Reichstag and in the courtroom at Nuremberg. And, retrospectively, we now see that during the war he was one of the most important photographers of what we now call the Holocaust. In the late 1940s, he was persecuted as a Jew; in the 1960s and 1970s, he was celebrated as a Soviet hero. In the 1990s and now, he is all of these things and more.

\section{Notes}

1 I base this number on reviews of dozens of lists of Soviet war photographers and attempts to determine which ones of them were Jewish. In interviews with many family members of these photographers, they estimated that at least 50 percent of photographers were Jewish.

2 See David Shneer, Through Soviet Jewish Eyes: Photography, War, and the Holocaust (New Brunswick: Rutgers University Press, 2010), Chap. 1.

3 On Kol'tsov see A. Rubashkin, Mikhail Kol'tsov (Leningrad: Khudozhestvennaia literatura, 1971); S. V. Iakovleva, "Predislovie," Mikhail Kol'tsov, Vostorg i iarost' (Moscow: Pravda, 1990).

4 Maks Al'pert, Bespokoinaia professiia (Moscow: Planeta, 1962).

5 "Biographical Information," The Semen Fridlyand Archive, Denver, Colorado. See also Rupert Jenkins, ed., Photography of Empire: Semyon Fridlyand Photographs (Denver: University of Denver Press, 2007). A third member of the Fridlyand family became one of the most important makers of Soviet visual culture-Boris Efimov, the country's most famous cartoonist. See Stephen Michael Norris, "The Visual World of Communism: Boris Efimov (Fridlyand) and the Soviet Century" (paper presented at the Association for the Advancement of Slavic Studies, Boston, MA, November 2009).

6 On Markov-Grinberg, see Paul Harbaugh, video interview with Mark MarkovGrinberg, June 1997, private archives of Teresa and Paul Harbaugh, Denver, CO. 
M. Markov, “Seria eshche ne zakonchena," Sovetskoe foto 11 (1937): 15-16. For more information on Markov-Grinberg, see David Shneer, Through Soviet Jewish Eyes.

7 Khaldei talks extensively about being born in 1917, but his sources reflecting his official, professional Soviet biography give 1916 as his birth year. See for example his official biographical form, in which he outlines his work history, and gives his birth year as 1916. Evgenii Khaldei Archives, housed at Agenstvo FotoSoyuz, Moscow. The files are not catalogued.

8 His work history is documented in archival records showing hiring and firing dates from his days in Iuzovka. These uncatalogued biographical records can also be found in Evgenii Khaldei Archives, at Agency FotoSoyuz, Moscow. See also David Shneer, "Jewgeni Chaldej und die jüdischen Fotografen der Sowjetunion," in Jewgeni Chaldej: Der bedeutende Augenblick, eds. Ernest Voller and Heinz Krimmer (Leipzig: Neuer Europa Verlag, 2008).

9 See TASS prikaz 119, October 19, 1942. Uncatalogued document in the Khaldei Files of the Voller Ernst Archives, Berlin.

10 Ogonek June 25, 1941, no. 18. On how the Holocaust unfolded on the pages of the Soviet press, see Karel Berkhoff, "Total Annihilation of the Jewish Population: The Holocaust in the Soviet Media, 1941-1945," Kritika (Spring 2009): 61-105.

11 See David Shneer, "Picturing Grief: Soviet Holocaust Photography at the Intersection of History and Memory," American Historical Review (February 2010): 1-25.

Il'ia Erenburg, Russia at War (London: Hamilton, 1943), 130-31.

13 Dnevnik Evgeniia Khaldeiia, ianvar' 1942g., in Evgenii Khaldei Archives, Agenstvo FotoSoyuz. Much of Khaldei's diary was recently published in German and lavishly illustrated. See Jewgeni Chaldej, ed., Kriegstagebuch (Berlin: Das Neue Berlin, 2011). voennym sovetam i nachal'nikam politicheskikh upravlenii frontov o prisylke $\mathrm{v}$ Glavpu RKKA fotodokumentov," Tsentral'nyi arkhiv Ministerstva oborony (TsAMO), f. 32, op. 920265, d. 3, l. 157 (August 1, 1941), as printed in V. A. Zolotarev, ed., Velikaia Otechestvennaia (Moscow: Terra, 1996), 55.

Dov Ber Kerler, “The Soviet Yiddish Press: Eynikayt 1942-1945," in "Why Didn't the Press Shout?": American and International Journalism during the Holocaust, ed. Robert Moses Shapiro (New York: Yeshiva, 2003), 221-50.

On the anti-cosmopolitan campaign, the Doctor's Plot, and other examples of postwar state-sponsored antisemitism, see Joshua Rubenstein and V. P. Naumov, eds., Stalin's Secret Pogrom: The Postwar Inquisition of the Jewish Anti-Fascist Committee (New Haven, CT: Yale University Press, 2001). See also David Brandenberger, "Stalin's Last Crime?: Recent Scholarship on Postwar Antisemitism and the Doctor's Plot," Kritika 6.1 (Winter 2005): 187-204; Jonathan Brent and Vladimir P. Naumov, Stalin's 
Last Crime: The Plot against the Jewish Doctors, 1948-1953 (New York: Harper Collins, 2003); G. V. Kostyrchenko, Tainaia politika Stalina: vlast' i antisemitizm (Moscow: Mezhdunarodnye otnosheniia, 2001). Joshua Rubenstein, Tangled Loyalties: The Life and Times of Ilya Ehrenburg (New York: Basic Books, 1996), 372-76. See also Louis Rapoport, Stalin's War against the Jews (New York: Free Press, 1990).

21 See G. Kostyrchenko, ed., Gosudarstevennyi antisemitizm v SSSR, 1938-1953 (Moscow: Materik, 2005) and Kostyrchenko, Tainaia politika Stalina.

22 The materials documenting Khaldei's relationship with TASS authorities can be found in the Khaldei Archive housed at Agenstvo FotoSoyuz in Moscow. The archive is not organized or catalogued. See for example "Zav Fotokhroniki TASS P. Serebriannikov Tov. Khavinsonu, Otvet. Rukovoditeliu TASS” (June 1943); or a letter from Khaldei requesting to challenge the order to return his photographic equipment (November 16, 1946), or N. Kuzovkin, "Predsedatel' attestatsionnoi kommissii i chleny kommissii attestatsii, tekst attestatsii Khaldeiia" (December 1947). The archive also holds the document telling Khaldei he has been "downsized." See Spravka, October 25, 1948.

23 The Jewish Museum of New York mounted an exhibition in Spring 1997, and the Jewish Museum of San Francisco in Summer/Fall 1997. For the documentary, see "Evgueni Khaldei-Photographer Under Stalin" (dir. Marc-Henri Wajnberg, 1997).

24 Alice and Alexander Nakhimovsky, eds., Witness to History: The Photographs of Yevgeny Khaldei (New York: Aperture, 1997).

25 Douglas Martin, "Yevgeny Khaldei, 80, War Photographer, Dies," New York Times, October 9, 1997.

26 See http://cityscan.ru/catalog.php?view=687 (accessed October 30, 2013). The original Russian reads: "Ia idu po ulochke, a eti dvoe mne navstrechu. Khotia v obshchemto znali, chto sovetskie voiska voshli, zhenshchina ostanovilas', i kakoe-to napriazhenie pochuvstvovalos'. Ia nachal po-nemetski im ob'iasnit', chto ia russkii, sovetskii. Zhenshchina rasplakalas'. Ia ikh sfotografiroval, a potom oni priamo u menia na glazakh stali sryvat' zvezdy, kotorye u nikh byli nashity na pal'to." In my September 2007 interview with Khaldei's daughter, she insisted again that the photograph had never been published in the Soviet Union, until I showed her scanned images of the Yiddish newspaper from March 1945.

27 Nakhimovsky, Witness to History, 10.

28 For this project on Khaldei, I interviewed many family members, collectors, and others who were familiar with these photographers. In the following interviews, the issue of the "Jewish Couple"s unpublishability came up: Anna Khaldei, Andrei Baskakov, Paul Harbaugh, Ernst Volland, and conversations with the Nakhimovskys.

29 See, for example, Neil Gabler, An Empire of Their Own: How Jews Invented Hollywood (New York: Anchor, 1989). J. Hoberman and Jeffrey Shandler, eds., Entertaining America: Jews, Movies, and Broadcasting (Princeton: Princeton University Press, 2005). Max Kozloff, "Jewish Sensibility and the Photography of New York," in New York: Capital of Photography (New Haven: Yale University Press, 2002).

30 Zvi Gitelman, "Internationalism, Patriotism, and Disillusion: Soviet Jewish Veterans Remember World War II and the Holocaust," in Holocaust in the Soviet Union, occasional paper, US Holocaust Memorial Museum, Washington, DC, November 2005. 